\title{
Zeolite inclusion in dog extruded diets: digestibility, fecal characteristics, and palatability
}

\section{Inclusão de zeólita em dietas extrusadas para cães: digestibilidade, características fecais e palatabilidade}

\author{
Fernanda Gonçalves Lowndes ${ }^{1}$; Tabyta Tamara Sabchuk ${ }^{2}$; Larissa Wünsche \\ Risolia $^{1}$; Ananda Portella Félix ${ }^{3}$; Alex Maiorka ${ }^{3}$; Simone Gisele de Oliveira ${ }^{3 *}$
}

\begin{abstract}
Addition of zeolite to caninedietscan improve fecal characteristics, reducing its moisture and odor. The objective of this study was to evaluate the effects of an increasing dietary inclusion of zeolite on nutrient and energy digestibility, fecal characteristics, and diet palatability for dogsfed diets containing high soybean meal level. Two experiments were performed. The first experiment evaluated the effect of increasing concentrations $(0,10,20,30,40$, or $50 \mathrm{~g} / \mathrm{kg})$ of zeolite (clinoptilolite) in extruded dog foods on diet digestibility and fecal quality. Six adult dogs were distributed to treatments arranged in a $6 \times 6$ Latin square design. The second assessed the effect of 20 or $50 \mathrm{~g}$ clinoptilolite per $\mathrm{kg}$ of diet on food palatability, where in 20 dogs were distributedinto two tests, in a completely randomized experimental design $(0 v s .20 \mathrm{~g} / \mathrm{kg}$ and $0 v s .50 \mathrm{~g} / \mathrm{kg}$ zeolite). Despite the small variation, dietary zeolite inclusion reduced diet metabolizable energy content $(15.4$ to $14.7 \mathrm{MJ} / \mathrm{kg}, \mathrm{P}<0.05)$ and the coefficient of total tract apparent digestibility of dry matter $(0.773$ to $0.740, \mathrm{P}<0.05)$. Fecal dry matter (fDM) content increased as zeolite concentrations increased $(30.4 \%$ to $36.1 \%, \mathrm{P}<0.05)$, but fecal score had no effect. Zeolite concentrations caused no changes $(\mathrm{P}>0.05)$ in ammonia nitrogen, sialic acid, fecal $\mathrm{pH}$,or diet palatability.The inclusion of up to $50 \mathrm{~g}$ natural clinoptilolite per $\mathrm{kg}$ of diet increases fDM content, maintains adequate fecal score and has no negative impact on diet palatability.
\end{abstract}

Key words: Adsorption capacity. Aluminosilicate. Clinoptilolite. Dogs.

\section{Resumo}

O uso de zeólita na alimentação de cães é realizado visando melhorar as características fecais, reduzindo sua umidade e odor. O presente trabalho teve como objetivo avaliar a inclusão crescente de zeólita sobre a digestibilidade dos nutrientes e energia, características fecais e palatabilidade de cães alimentados com dieta contendo altos níveis de farelo de soja. Foram realizados dois experimentos. O primeiro avaliou a inclusão crescente de zeólita (clinoptilolita): 0, 10, 20, 30, 40 e $50 \mathrm{~g} / \mathrm{kg}$ em dietas extrusadas para cães sobre a digestibilidade e qualidade das fezes. Foram utilizados seis cães adultos, em quadrado latino 6x6. No segundo experimento avaliou-se a inclusão de 20 e $50 \mathrm{~g} / \mathrm{kg}$ de clinoptilolita na dieta sobre a palatabilidade em cães. Foram utilizados 20 cães em delineamento inteiramente casualizado em dois tratamentos $(0 v s .20 \mathrm{~g} / \mathrm{kg}$ e 0 vs. $50 \mathrm{~g} / \mathrm{kg}$ de zeólita). Embora com pequena variação, a inclusão de zeólita

1 Discentes, Curso de Mestrado, Programa de Pós-Graduação em Ciências Veterinárias, Universidade Federal do Paraná, UFPR, Curitiba, PR, Brasil. E-mail: fernandalowndes@gmail.com; larissa.risolia@gmail.com

2 Discente, Curso de Doutorado, Programa de Pós-Graduação em Zootecnia, UFPR, Curitiba, PR, Brasil. E-mail: ttsabchuk@, gmail.com

3 Profs., Departamento de Zootecnia, UFPR, Curitiba, PR, Brasil. E-mail: apfelix@ufpr.br; amaiorka@ufpr.br; sgoliveira@ufpr.br

* Author for correspondence 
resultou em redução linear da energia metabolizável $(15,4$ a 14,7 MJ $/ \mathrm{kg}, \mathrm{P}<0,05)$ e do coeficiente de digestibilidade aparente da matéria seca $(0,773$ a $0,740, \mathrm{P}<0,05)$. A matéria seca fecal aumentou com os níveis crescentes de zeólita $(30,4 \%$ a $36,1 \%, \mathrm{P}<0,05)$ não afetando, entretanto, o escore das fezes. Os níveis de zeólita não causaram diferença quanto ao nitrogênio amoniacal, ácido siálico e pH fecal $(P>0,05)$. Não foram encontradas diferenças na palatabilidade das dietas. A inclusão de até $50 \mathrm{~g} / \mathrm{kg}$ de clinoptilolita natural aumenta o teor de matéria seca fecal, com manutenção de adequado escore fecal, sem afetar negativamente a palatabilidade das dietas.

Palavras-chave: Aluminosilicato. Cães. Capacidade adsorvente. Clinoptilolita.

\section{Introduction}

A share of studies on dog nutrition has focused on developing food additives to improve fecal texture and reduce its odor without affecting food palatability and digestibility (MAIA et al., 2010). The balanced food industry for dogs and cats pays special attention to fecal characteristics, as it is an important factor in the choice of purchase by pet owners.

Soybean meal is widely used as a pet food ingredient.It contains $20 \%$ non-starch polysaccharides (NSP), which can be classified as soluble or insoluble. NSP can reduce dietary nutrient digestibility and energy content. Soluble NSP may do this by increasing digesta viscosity in the gastrointestinal tract (GIT) and reduce transit time, and thus hindering access of digestive enzymes and interfering with nutrient diffusion and transport (BRITO et al., 2008). Conversely, insoluble NSP increases fecal volume and render feces softer, thereby increasing evacuation times (MATTOS; MARTINS, 2000).

Adsorbent additives, such as zeolites, may mitigate deleterious effects of NSP on dog fecal characteristics, since they adsorb water and gas and decrease ammonia excretion, improving fecal characteristics and reducing its odor (FÉLIX et al., 2009). Zeolites are hydrated aluminosilicates of alkaline or alkaline-earth metals, whose structure consists of rigid three-dimensional crystalline networks of aluminum oxide and silicon oxide tetrahedra (LUZ, 1995). These are important raw materials for the pet food industry, as they allow higher inclusion levelsof fermentable ingredients in foods. These metals can reduce the negative effects of fermentation by decreasing ammonia emission and absorbing gases, which in turn improve fecal characteristics and increasefinal product acceptance by pet owners (MAIA et al., 2010).

Given the foregoing, this study aimed to evaluate food palatability, nutrient and energy digestibility, and fecal characteristics for dogs fed diets with high soybean meal content and increasing zeolite concentrations.

\section{Materials and Methods}

The experiments were approved by the Committee of Ethics on Animal Use of the Federal University of Paraná, Curitiba, PR, Brazil.

\section{Experiment 1: digestibility trial}

\section{Animals and housing}

We tested six adult Beagle dogs (three males and three females), with $4.0 \pm 0.1$ years of age and $10 \pm 1.2 \mathrm{~kg}$ average body weight (BW). During digestibility trial, the dogs were housed in individual concrete kennels (5-m long x 2-m wide) with a roof.

\section{Experimental diets}

Six complete and balanced diets were formulated to meet the nutritional requirements of dogs in maintenance according to NRC (2006). Diets contained $30 \%$ soybean meal differing by inclusion of $0,10,20,30,40$, or $50 \mathrm{~g} / \mathrm{kg}$ of a zeolite species (clinoptilolite, CELPEC, Celta Brasil, Cotia, Brazil), 
at the expense of corn. Clinoptilolite is a $100 \%$ natural product consisting of a crystalline hydrated aluminosilicate with an internal surface of 300 $\mathrm{m}^{2} / \mathrm{g}$. It presents a $\mathrm{Si} / \mathrm{Al}$ ratio of 4.25 and a cationexchange capacity (CEC) of $2.6 \mathrm{mEq} / \mathrm{g}$. Following the method described by Bish and Reynolds Junior
(1989), we performed x-ray diffraction of the zeolite used and observed the same peaks as those in the reference 39-1383 (clinoptilolitepattern) fromthe database of the International Center for Diffraction Data (ICDD). Table 1 shows the ingredients and chemical composition of the experimental diets.

Table 1. Ingredients and analyzed chemical composition of the experimental diets.

\begin{tabular}{lcccccc}
\hline \multirow{2}{*}{ Item } & \multicolumn{7}{c}{ Zeolite $(\mathrm{g} / \mathrm{kg})$} \\
\cline { 2 - 7 } Ingredient (g/kg, as fed) & 0 & 10 & 20 & 30 & 40 & 50 \\
Corn & 492.40 & 482.40 & 472.40 & 462.40 & 452.40 & 442.40 \\
Poultry fat & 40.00 & 40.00 & 40.00 & 40.00 & 40.00 & 40.00 \\
Soybean meal 46\% & 300.00 & 300.00 & 300.00 & 300.00 & 300.00 & 300.00 \\
Meat meal & 40.00 & 40.00 & 40.00 & 40.00 & 40.00 & 40.00 \\
Poultry offal meal & 80.00 & 80.00 & 80.00 & 80.00 & 80.00 & 80.00 \\
Salt & 5.00 & 5.00 & 5.00 & 5.00 & 5.00 & 5.00 \\
Poultry hydrolysate & 30.00 & 30.00 & 30.00 & 30.00 & 30.00 & 30.00 \\
BHA & 0.08 & 0.08 & 0.08 & 0.08 & 0.08 & 0.08 \\
BHT & 0.15 & 0.15 & 0.15 & 0.15 & 0.15 & 0.15 \\
Citric acid & 0.37 & 0.37 & 0.37 & 0.37 & 0.37 & 0.37 \\
Calcium propionate & 3.00 & 3.00 & 3.00 & 3.00 & 3.00 & 3.00 \\
Choline chloride & 4.00 & 4.00 & 4.00 & 4.00 & 4.00 & 4.00 \\
Mineral-vitamin Supplement ${ }^{\mathrm{a}}$ & 5.00 & 5.00 & 5.00 & 5.00 & 5.00 & 5.00 \\
Zeolite & 0.00 & 10.00 & 20.00 & 30.00 & 40.00 & 50.00 \\
Total & 1,000 & 1,000 & 1,000 & 1,000 & 1,000 & 1,000 \\
Analyzed chemical compositionyyyyyy$(\mathrm{g} / \mathrm{kg}, \mathrm{dry}$ & matter basis) & & & & \\
DM & 918.1 & 921.6 & 896.7 & 908.5 & 912.1 & 923.8 \\
Ash & 69.9 & 71.3 & 75.4 & 90.6 & 96.0 & 105.9 \\
CP & 266.3 & 240.6 & 256.7 & 264.9 & 261.9 & 264.8 \\
NDF & 189.8 & 189.2 & 182.9 & 201.0 & 209.5 & 206.8 \\
ADF & 59.7 & 60.1 & 62.3 & 70.2 & 69.9 & 68.2 \\
CF & 24.8 & 21.6 & 26.4 & 25.9 & 25.8 & 24.6 \\
EEAH & 108.3 & 112.8 & 112.8 & 115.1 & 118.3 & 116.6 \\
Ca & 17.7 & 16.8 & 13.7 & 16.5 & 15.7 & 17.0 \\
P & 9.7 & 9.6 & 9.4 & 9.5 & 9.1 & 9.8 \\
\hline
\end{tabular}

BHA: butylated hydroxyanisole, BHT: butylated hydroxytoluene.

DM: dry matter, CP: crude protein, NDF: neutral detergent fiber, ADF: acid detergent fiber, CF: crude fiber, EEHA: ether extract after acid hydrolysis, Ca: Calcium, P: Phosphorus.

${ }^{a}$ Vitamin-mineral supplement (content/kg of diet): $20000 \mathrm{IU}$ vit. A, $2000 \mathrm{IU}$ vit. D, 48mg vit. K, 4mg vit. B1, 32mg vit. B2, $16 \mathrm{mg}$ pantothenicacid, $56 \mathrm{mg}$ niacin, $800 \mathrm{mg}$ choline, $150 \mathrm{mg}$ zinc, $100 \mathrm{mg}$ iron, $15 \mathrm{mg}$ copper, $1.5 \mathrm{~m}$ iodine, $30 \mathrm{mg}$ magnesium, $0.2 \mathrm{mg}$ selenium, and $240 \mathrm{mg}$ antioxidant.

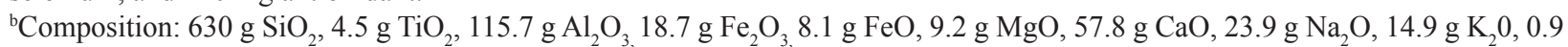
$\mathrm{g} \mathrm{P}_{2} \mathrm{O}_{5}$ and $34.4 \mathrm{~g} \mathrm{H}_{2}$. 


\section{Experimental procedures}

Before the experiment started, diet samples were analyzed for contents of dry matter (DM), crude protein (CP, method 954.01), ash (Ash, method 942.05), crude fiber (CF, method 962.10), and ether extract after acid hydrolysis (EEAH, method 954.02), according to the AOAC (1995) method. Neutral detergent soluble fiber (NDF) and acid detergent soluble fiber (ADF) contents were determined by the method of Van Soest (1991). Gross energy (GE) was determined in a calorimetric bomb (Parr Instrument Co., model 1261, Moline, IL, USA).

The digestibility trial was performed using the method of total feces collection, according to the recommendations of the Association of American Feed Control Officials (AAFCO, 2004). The trial was divided into six periods of 10 days (five days of adaptation followed by five days of total feces collection). Dogs were fed twice daily, at $8 \mathrm{am}$ and $4 \mathrm{pm}$,in enough quantity to supply their maintenance energy (ME) requirements, as recommended by the $\mathrm{NRC}$ (2006), i.e.: $\mathrm{MJ} /$ day $=0.54 \times \mathrm{BW}^{0.75}$. Water was supplied ad libitum. Feces were collected at least twice daily, and the samples were weighed and frozen $\left(-14^{\circ} \mathrm{C}\right)-$ per individual dog, and pooled per collection period.

Fecal $\mathrm{pH}$ and ammonia were measured in duplicate in fresh feces collected no more than 15 minutes after defecation. Fecal $\mathrm{pH}$ was determined in $2.0 \mathrm{~g}$ fresh feces diluted in $20 \mathrm{~mL}$ distilled water, using a digital $\mathrm{pHmeter}$ (331, Politeste Instrumentos de Teste LTDA, São Paulo, SP, Brazil). Fecal ammonia content was determined according to Brito et al. (2010) in $5 \mathrm{~g}$ fresh feces, which were incubated in a 500-mL lidded glass balloon with 250 $\mathrm{mL}$ distilled water for one hour. Three drops of octaethyl alcohol (1-octanol) and $2 \mathrm{~g}$ magnesium oxide were then added. This mixture was distilled using a macro-Kjeldahl apparatus and recovered in a beaker containing $50 \mathrm{~mL}$ boric acid. Finally, ammonia was titrated using $0.1 \mathrm{~N}$ standard sulfuric acid. Ammonia concentration was calculated as follows: Ammoniacal nitrogen $(\mathrm{g} / \mathrm{kg})=\mathrm{N}$ x correction factor x 17 x [(volume of acid in the sample - volume of acid in blank sample)/sample weight in grams].

Fecal texture was scored according to a 1-5 scale, wherein: $1=$ watery feces (could be easily poured from a container); 2 = unshaped stool (takes the shape of the container); $3=$ soft, shaped, and moist stool; 4 = firm, shaped, dry stool (remains firm and soft); 5 = hard, dry pellets (small, hard masses) (CARCIOFI et al., 2009). After collection, the pool of feces of each dog was thawed and homogenized,out of which $20 \mathrm{~g}$ were submitted to freeze-drying and subsequent measurement of fecal sialic acid content, according to the method proposed by Jourdian et al. (1971). The remaining feces were dried in a forced-ventilation oven (320$\mathrm{SE}$, Fanem, São Paulo, Brazil) at $55^{\circ} \mathrm{C}$ for 72 hours, and then ground in a Wiley mill (Arthur H. Thomas Co., Philadelphia, PA, USA), using a $1 \mathrm{~mm}$ screen before being submitted to DM, CP, Ash, CF, EEAH, and GE content analyses,following the abovementioned methods.

\section{Total tract apparent digestibility coefficients}

Coefficients of total tract apparent digestibility (CTTAD) of the analyzed diets were calculated based on laboratory results, using the following equations: CTTAD $(\%)=[(\mathrm{g}$ nutrient intake $-\mathrm{g}$ nutrient excretion)/g nutrient intake] x 100. Also, metabolizable energy was estimated according to the Association of American Feed Control Officials (2004), as follows: $\mathrm{ME}(\mathrm{MJ} / \mathrm{kg})=\{\mathrm{MJ} / \mathrm{g}$ gross energy intake $-\mathrm{MJ} / \mathrm{g}$ gross energy excreted in feces $-[(\mathrm{g}$ crude protein intake $-\mathrm{g}$ crude protein excreted in feces) $x 5.23 \mathrm{MJ} / \mathrm{g}]\} / \mathrm{g}$ food intake. 
Experimental design and statistical analyses

The experiment was carried out in a $6 \times 6$ Latin square experimental design, with six treatments, six periods, and six replicates per treatment. The results were submitted to the Shapiro-Wilk normality test and to Bartlett's homoscedasticity test. The data with normal distribution were submitted to analysis of regression, using the PROC REG procedure of SAS statistical package (version 8 , SAS Institute Inc., NC, USA). Fecal score, $\mathrm{pH}$, and ammoniacal nitrogen are non-parametric variables and therefore were analyzed by the Kruskal-Wallis' test at 5\% probability level, also using SAS.

\section{Experiment 2:palatability trial}

\section{Animals and housing}

Twenty male $(\mathrm{n}=10)$ and female $(\mathrm{n}=10)$ adult dogs, $6.3 \pm 1.4$ years of age, were individually housed in concrete kennels with a solarium measuring 5 $\mathrm{m} \times 2 \mathrm{~m}$. Eight Beagles $(12.4 \pm 1.1 \mathrm{~kg} \mathrm{BW})$, four Labradors (27.9 $\pm 2.3 \mathrm{~kg} \mathrm{BW})$, four Basset Hounds (20.7 $\pm 2.0 \mathrm{~kg} \mathrm{BW}$ ), and four Siberian Huskies (21.6 $\pm 1.5 \mathrm{~kg} \mathrm{BW}$ ) were included in the trial.

\section{Experimental diets}

Palatability trial included two tests: 0 vs. 20 $\mathrm{g} / \mathrm{kg}$ dietary inclusion of zeolite (clinoptilolite) during food extrusion, and $0 v s .50 \mathrm{~g} / \mathrm{kg}$ of the same adsorbent. Food allowance was 30\% higher than the recommendations of the NRC (2006) for the maintenance of adult dogs.

\section{Experimental procedures}

Both diets were simultaneously offered, once daily (5 pm), using two different bowls, duly identified for comparison purposes. The dogs had access to the foods for 30 minutes and did not receive any other food during the day. Each test was repeated for two consecutive days. The position of bowls was daily changed to prevent bowl placement from biasing dogs' behavior.

Palatability was determined by measuring food preference and the first choice between both offered foods. The amounts of food offered and food residues were quantified using food preference calculation. The first choice was determined by recording the first bowl to which the dog approached at the time bowls were presented. Food preference was calculated as a function of relative intake (offer - residues) of diets $\mathrm{A}$ and $\mathrm{B}$, as follows:

Food preference $(\%)=[\mathrm{g} \operatorname{diet} \mathrm{A}$ or B intake/ $\mathrm{g}$ total food offered $(\mathrm{A}+\mathrm{B})] \mathrm{x} 100$.

\section{Experimental design and statistical analyses}

A completely randomized experimental design was applied, with 40 replicates ( 20 dogs $\times$ two days per test) per treatment. Each dog was considered as an experimental unit. The first-choice data were submitted to a chi-square test, and the Student's t-test was used to evaluate food preference (intake ratio), both at a $5 \%$ probability level.

\section{Results and Discussion}

The inclusion of increasing concentrations of clinoptilolite in the food linearly reduced ME content and dry matter digestibility (CTTAD), and linearly increased fecal dry matter (fDM, $\mathrm{P}<0.05$, Table 2). The CTTAD of the other evaluated nutrients (OM, CP, EEAH, and GE) were not influenced by dietary clinoptilolite inclusion $(\mathrm{P}>0.05$, Table 2$)$. Also, no effect of treatments on fecal $\mathrm{pH}$, score, or ammoniacal nitrogen and sialic contents was detected $(\mathrm{P}>0.05$, Table 3$)$. 
Table 2. Coefficients of total tract apparent digestibility, metabolizable energy (ME, MJ/kg), and fecal dry matter (fDM, \%) of dogs fed diets with increasing zeolite levels.

\begin{tabular}{|c|c|c|c|c|c|c|c|c|c|}
\hline \multirow{2}{*}{ Item } & \multicolumn{4}{|c|}{ Zeolite $(\mathrm{g} / \mathrm{kg})$} & \multirow[b]{2}{*}{40} & \multirow[b]{2}{*}{50} & \multirow{2}{*}{ SEM } & \multicolumn{2}{|c|}{ P value } \\
\hline & 0 & 10 & 20 & 30 & & & & $\mathrm{~L}$ & Q \\
\hline \multicolumn{10}{|c|}{ Coefficient of total tract apparent digestibility } \\
\hline $\mathrm{DM}^{\mathrm{a}}$ & 0.773 & 0.789 & 0.778 & 0.766 & 0.751 & 0.740 & 0.44 & 0.003 & 0.125 \\
\hline $\mathrm{OM}$ & 0.824 & 0.830 & 0.818 & 0.823 & 0.822 & 0.818 & 0.48 & 0.602 & 0.991 \\
\hline $\mathrm{CP}$ & 0.823 & 0.818 & 0.821 & 0.824 & 0.809 & 0.820 & 0.30 & 0.601 & 0.901 \\
\hline EEAH & 0.859 & 0.876 & 0.874 & 0.881 & 0.874 & 0.867 & 0.42 & 0.353 & 0.362 \\
\hline GE & 0.851 & 0.854 & 0.858 & 0.845 & 0.836 & 0.843 & 0.34 & 0.686 & 0.870 \\
\hline $\mathrm{fDM}^{\mathrm{b}}$ & 30.40 & 33.60 & 33.70 & 34.30 & 34.20 & 36.10 & 0.65 & 0.000 & 0.197 \\
\hline $\mathrm{ME}^{\mathrm{c}}$ & 15.40 & 15.40 & 14.70 & 14.70 & 14.70 & 14.70 & 28.10 & 0.015 & 0.277 \\
\hline
\end{tabular}

DM: dry matter, OM: organic matter, CP: crude protein, EE: ether extract after acid hydrolysis, GE: gross energy, fDM: fecal dry matter, ME: metabolizable energy.

SEM: standard error of the mean.

L: linear, Q: quadratic.

${ }^{\mathrm{a}} \mathrm{y}=-0.713 \mathrm{x}+81.36, \mathrm{R}^{2}=0.6756$.

${ }^{b} y=0.6767 x+32.76, R^{2}=0.577$.

${ }^{c} y=-27.122+3667.5$ e $R^{2}=0.6991$.

Table 3. Medians of fecal pH, score, and ammoniacal nitrogen (on dry matter basis) and sialic acid contents of dogs fed diets with increasing zeolite levels.

\begin{tabular}{lccccc}
\hline Zeolite $(\mathrm{g} / \mathrm{kg})$ & Intake $(\mathrm{g} / \mathrm{kg}$ BW/day) & Ammoniacal nitrogen $(\mathrm{g} / \mathrm{kg})$ & $\mathrm{pH}$ & Fecal Score & Sialic acid $(\mu \mathrm{mol} / \mathrm{g})$ \\
\hline 0 & 16.84 & 1.69 & 6.45 & 4.00 & 0.854 \\
10 & 15.09 & 2.14 & 6.10 & 3.50 & 0.846 \\
20 & 16.76 & 2.13 & 5.91 & 4.00 & 0.897 \\
30 & 15.98 & 2.40 & 6.19 & 4.00 & 0.999 \\
40 & 15.23 & 2.55 & 6.05 & 4.00 & 0.993 \\
50 & 16.09 & 2.52 & 6.47 & 4.00 & 0.945 \\
P value & 1.000 & 0.065 & 0.381 & 0.428 & 0.317 \\
\hline
\end{tabular}

The $0.7 \mathrm{MJ}$ reduction in dietary $\mathrm{ME}$ content between the control treatment and the treatment with the highest clinoptilolite concentration $(0$ and $50 \mathrm{~g} / \mathrm{kg}$, respectively) may be explained by the fact that the aluminosilicate was included at the expense of corn, thereby reducing diet energy supply. Corn is the main source of starch and energy in Brazilian extruded dog foods. According to Sá-Fortes et al. (2010), corn contains $16.0 \mathrm{MJ} / \mathrm{kg}$. Therefore, considering its replacement by zeolite at $50 \mathrm{~g} / \mathrm{kg}$, this represents a reduction of $0.8 \mathrm{MJ}$ in dietary $\mathrm{ME}$ content, which is consistent with the results obtained in the present study.
The replacement of corn with clinoptilolite in the formulation of diets also explains the linear reduction in DM digestibility encountered here. Corn digestible nutrients were replaced with a material that is inert in the dog GIT, as demonstrated by the absence of effect on organic matter digestibility.

Regarding the changes in fecal characteristics, fDM increased linearly with increasing zeolite concentrations. This result is consistent with the findings of Félix et al. (2009) and Maia et al. (2010) - in studies with dogs, and with Santos et al. (2011) and Roque et al. (2011) - in studies with cats. 
Zeolite adsorbs water from the intestinal content and retains it inside its several internal channels, and therefore reducing fecal moisture. This is explained by the tridimensional structure of aluminosilicates, which creates a large internal surface area of about $300 \mathrm{~m}^{2} / \mathrm{g}$, with interconnecting channels that can be occupied by ions and free-moving water molecules (LUZ, 1995).

Interestingly, despite the expected differences due to dietary inclusion of $30 \%$ soybean meal, the observed increase in fDM had no effect on fecal scores, which remained at adequate concentrations, as stated by Félix et al. (2009). The absence of fecal score differences may be ascribed to the subjectivity of fecal scoring, and therefore this evaluation should be complemented with a quantitative method, such as fDM analysis. The linear increase in fDM demonstrates effective water adsorption in the GIT of dogs by zeolite.

Brazilian standard level of zeolite inclusion incomplete dog foods is $10 \mathrm{~g} / \mathrm{kg}$ (MAIA et al., 2010). According to our results, this level promoted adequate $\mathrm{CAD}$ and $\mathrm{fDM}$ results. The significant increase in $\mathrm{fDM}$ and better fecal scores obtained by Félix et al. (2009) may be attributed to the fact that these authors used a mixture of aluminosilicates and not only natural clinoptilolite, as in the present study. According to Luz (1995), the 42 types of natural zeolites present different adsorption and CEC, which may explain the wide diversity of results obtained when these minerals are included in dog foods (FÉLIX et al., 2009; MAIA et al., 2010). Another hypothesis for the difference between the present study and the findings of Félix et al. (2009) is that the latter included 'on top' mixture of aluminosilicate, after the extrusion process. When included in foods by this method, zeolites do not suffer any influences of food processing, and it may be protected by fat until it reaches the dog small intestine, exerting its action in the large intestine.

The absence of a reduction in ammoniacal nitrogen in feces found in this study is not consistent with the findings of Félix et al. (2009) and Maia et al. (2010) in studies with dogs, and of Roque et al. (2011), in studies with cats.Such reduction was expected since aluminosilicates limit the development of pathogenic microorganisms that ferment nitrogen compounds, because they retain alkaline substances, reducing GIT $\mathrm{pH}$. In addition, aluminosilicates present significantpotential forgas adsorption in the GIT (LUZ, 1995). The inclusion of zeolites in animal foods may prevent intestinal absorption of ammonia. According to Wang and Peng (2010), the ammonia adsorption capacity by natural zeolites ranges between 1.5 and $30.6 \mathrm{mg} / \mathrm{g}$. This wide range stresses the importance of a suitable characterization of zeolites included in foods.

The impact of nutrients on digestive physiologyof dogs should be considered when evaluating foods. One indirect measure is the content of sialic acid in feces. According to Jourdian et al. (1971), sialic acid is a constituent of mucin, whose production increases when the intestinal wall is damaged. In the present study, fecal concentrations of sialic acid were not influenced by the treatments, which may indicate that the inclusion of up to $50 \mathrm{~g}$ clinoptilolite per $\mathrm{kg}$ food hasno direct effect on the intestinal wall of dogs.

In the palatability trial, no statistical differences among treatments were detected in terms of the first choice and intake ratio $(\mathrm{P}>0.05$, Table 4$)$.

Table 4. Number of dogs choosing as first choice the diet A and intake ratio (IR; mean \pm standard error) of dogs fed diets containing 20 and $50 \mathrm{~g} / \mathrm{kg}$ zeolite.

\begin{tabular}{llc}
\hline Diet & $\mathrm{N}^{\mathrm{a}}$ & Diet IR \\
\hline 0 vs. $20 \mathrm{~g} / \mathrm{kg}$ zeolite & 17 & $0.47+0.0286$ \\
0 vs. $50 \mathrm{~g} / \mathrm{kg}$ zeolite & 18 & $0.48+0.0471$ \\
\hline
\end{tabular}

${ }^{a}$ First choice of the bowl containing $\operatorname{diet}$ A. B is calculated as 40-n.

${ }^{\mathrm{b}}$ IR of diet control = intake $(\mathrm{g})$ of diet control / total intake $(\mathrm{g}$; diets of diets control + treatment). Diet treatment IR is calculated as 1 -IR of diet control. 
Food preference can be assessed using palatability trials and should be considered when additives are included in dog foods. In the present study, no differences in food palatability were detected, which is in agreement with the results of Félix et al. (2009) and Maia et al. (2010), in studies with dogs, and with Roque et al. (2011) and Santos et al. (2011), in studies with cats. Therefore, the evaluated zeolite does not reduce the palatability of extruded dog foods.

\section{Conclusions}

The inclusion of increasing concentrations of natural clinoptilolite in dog foods, at the expense of corn, dilutes dietary metabolizable energy. When used as a food additive, natural clinoptilolite increases fecal dry matter content, maintains an adequate fecal score, and has no negative effect on diet palatability. However, due to the wide variation of results reported in the literature, the evaluated zeolite should be properly characterized.

\section{Acknowledgments}

The authors acknowledge VB Alimentos for the provision of the diets.

\section{References}

ASSOCIATION OF AMERICAN FEED CONTROL OFFICIALS - AAFCO. Dog and cat nutrient profiles. Oxford: AAFCO, 2004.

ASSOCIATION OF OFFICIAL ANALYTICAL CHEMISTS - AOAC. Official methods of analysis. $16^{\text {th }}$ ed. Washington: AOAC, 1995.

BISH, D. L.; REYNOLDS JUNIOR, R. C. Sample preparation for $\mathrm{x}$-ray diffraction. In: BISH, D. L.; POST, J. E. Modern powder diffraction. Washington: Mineralogy of America, 1989. v. 20, p. 73-99. (Reviews in Mineralogy).

BRITO, C. B. M.; FÉLIX, A. P.; JESUS, R. M.; FRANÇA, M. I.; OLIVEIRA, S. G.; KRABBE, E. K.; MAIORKA, A. Digestibility and palatability of dog foods containing different moisture levels, and the inclusion of a mould inhibitor. Animal Feed Science and Technology, Oxford, v. 159, n. 3-4, p. 150-155, 2010. DOI: 10.1016/j. anifeedsci.2010.06.001

BRITO, M. S.; OLIVEIRA, C. F.; SILVA, T. R. G.; LIMA, R. B.; MORAIS, S. N.; SILVA, J. H. V. Polissacarídeos não amiláceos na nutrição de monogástricos. Acta Veterinaria Brasilica, Mossoró, v. 2, n. 4, p. 111-117, 2008. DOI: $10.21708 / \mathrm{avb} .2008 .2 .4 .917$

CARCIOFI, A. C.; OLIVEIRA, L. D.; VALÉRIO, A. G.; BORGES, L. L.; CARVALHO, F. M.; BRUNETTO, M. A.; VASCONCELLOS, R. S. Comparison of micronized whole soybeans to common protein sources in dry dog and cat diets. Animal Feed Science and Technology, Oxford, v. 151, n. 3, p. 251-260, 2009. DOI: 10.1016/j. anifeedsci.2009.01.002

FÉLIX, A. P.; ZANATTA, C. P.; BRITO, C. B. B.; MURAKAMI, F. Y.; FRANÇA, M. I.; MAIORKA, A.; FLEMMING, J. S. Suplementação de manoligossacarídeos (MOS) e uma mistura de alumino silicatos na qualidade das fezes de cães adultos. Archives of Veterinary Science, Curitiba, v. 14, n. 1, p. 31-35, 2009.

JOURDIAN, G. W.; DEAN, L.; ROSEMAN, S. The sialic acids: a periodate-resorcinol method for the quantitative estimation of free sialic acids and their glycosides. Journal Biological Chemistry, Rockville, v. 246, n. 2, p. 430-435, 1971

LUZ, A. B. Zeólitas: propriedades e usos industriais. Rio de Janeiro: CETEM-CNPq, 1995. 36 p.. Disponível em: http://www.cetem.gov.br/publicacao/series_stm/stm-68. pdf. Acesso em: 2 mar. 2012.

MAIA, G. V. C.; SAAD, F. M. O. B.; ROQUE, N. C.; FRANÇA, J.; LIMA, L. M. S.; AQUINO, A. A. Zeólitas e Yucca schidigera em rações para cães: palatabilidade, digestibilidade e redução de odores fecais. Revista Brasileira de Zootecnia, Viçosa, MG, v. 39, n. 11, p. 24422446, 2010. DOI: 10.1590/S1516-35982010001100017

MATTOS, L. L.; MARTINS, P. Consumo de fibras alimentares em população adulta. Revista de Saúde Pública, São Paulo, v. 34, n. 1, p. 50-55, 2000. DOI: 10.1590/S0034-89102000000100010

NATIONAL RESEARCH COUNCIL - NRC. Nutrient requirements of dogs. Washington: NRC, National Academy Press, 2006.

ROQUE, N. C.; SAAD, F. M. O. B.; SANTOS, J. P. F.; EBINA, F. S.; CHIZZOTTI, A. F.; SILVA, R. C.; AQUINO, A. A.; MAIA, G. V. C. Increasing levels of zeolite and Yucca schidigera in diets for adult cats. Revista Brasileira de Zootecnia, Viçosa, MG, v. 40, n. 11, p. 2471-2475, 2011. DOI: 10.1590/S151635982011001100027 
SÁ-FORTES, C. L.; CARCIOFI, A. C.; SAKOMURA, N. K.; KAWAUCHI, I. M.; VASCONCELLOS, R. S. Digestibility and metabolizable energy of some carbohydrate sources for dogs. Animal Feed Science and Technology, Oxford, v. 156, n. 3, p. 121-125, 2010. DOI: 10.1016/j.anifeedsci.2010.01.009

SANTOS, J. P. F.; SAAD, F. M. O. B.; ROQUE, N. C.; AQUINO, A. A.; PIRES, C. P.; GERALD, I. L. F. Yuccaschidigera e zeólita em alimento para gatos adultos e seus efeitos na excreção de minerais. Arquivo Brasileiro de Medicina Veterinária e Zootecnia, Belo Horizonte, v. 63, n. 3, p. 687-693, 2011. DOI: 10.1590/ S0102-09352011000300021
VAN SOEST, P. J.; ROBERTSON, J. B.; LEWIS, B. A. Methods for dietary fiber, neutral detergent fiber, and non starch polysaccharides in relation to animal nutrition. Journal of Dairy Science, Champaign, v. 74, n. 10, p. 3583-3597, 1991. DOI: 10.3168/jds.S00220302(91)78551-2

WANG, S.; PENG, Y. Natural zeolites as effective adsorbents in water and waste water treatment. Chemical Engineering Journal, Oxford, v. 156, n. 1, p. 11-24, 2010. DOI: 10.1016/j.cej.2009.10.029 
